Рощенко Олена Георгіївна, доктор мистецтвознавства, професор, завідувач кафедри теорії та історії музики Харківської державної академії культури ORCID 0000-0002-6048-6335 elena.roshenko@gmail.com

\title{
МУЗИКОЗНАВЧЕ АКМЕ НАТАЛІЇ САВИЦЬКОЇ: НА ШЛЯХУ ДО МУЗИКОЛОГІЧНОЇ АКМЕОЛОГІЇ
}

Мета роботи - розкрити сутність музикознавчого акме Наталії Савицької на основі розробки засад музикологічної акмеології. Методологія дослідження базується на залученні інтердисциплінарного підходу, засад фундаментального музикознавства, акмеоцентричного підходу, застосованого задля спирання на сукупність методів акмеологічних наук з метою системного вивчення шляху музиканта-науковця до професійно-творчої досконалості. Наукова новизна полягає у розкритті сутності музикознавчого акме Н. Савицької, введенні поняття музикознавча життєтворчість, обґрунтуванні необхідності розробки музико логічної акмеології. Розвинено структуру вікового музикознавства - наукового invention $\mathrm{H}$. Савицької: його другий тип передбачає аналіз життєтворчості музикознавця крізь призму еволюції наукового мислення; третій різновид направлений на вивчення особистості виконавця, виконавської життєтворчості - втілення вікових змін у розвитку творчої особистості. Методологія вікового музикознавства спрацьовує після закінчення життєтворчості індивідууму: тоді життєтворча дуга, прочерчена душею й працею науковця-митця, вибудовується у повному обсязі; відбувається дистанціювання від спостерігаючого за їі акмеограмою дослідницького ока. Останнє дослідження Н. Савицької - вираз музикознавчого акме: втілення розквітлого таланту, досконалості наукової думки, духовної і професійної зрілості, кульмінація музикознавчої життєтворчості, яку вирізняють здібність до надання об'єктивної оцінки власним науковим концепціям та рефлексіям, концепційність та лаконізм. Вивчення вершинних досягнень науково-творчої особистості в процесі індивідуального розвитку професійної долі музиканта/музикознавця потребує розробки засад музикологічної акмеології - міждисциплінарної науки про професійно-особистістне самовдосконалення митця. До складу фундаментальної акмеології, утвореною системою акмеологічних наук, має увійти музикологічна акмеологія, що базується на взаємодії історії, біографіки, психології, педагогіки, культурології, соціології, класичних напрямів науки про музику, з метою комплексного вивчення особистості музиканта-науковця, який досяг зоряної години в творчості. Висновки. В особі Н. Савицькоїмузикознавця, чиї праці вирізняє своєрідність дослідницького «почерку», вільне поєднання фрілософсько-художнього типу мислення, наукового узагальнення і літературності викладення, проступала краса мудрої жінки. Траєкторія життєтворчості $\mathrm{H}$. Савицької засвідчує властиве героїні музикологічної акмеології тяжіння до професійних висот, досконалості наукового твору. Кульмінація життєвої дуги Н. Савицької співпала з фіналом життя музикознавця. Особистість Н. Савицької відповідає критеріям професійно-особистісної досконалості науково-творчого суб'єкта, який перебуває на вершині музикознавчої науки, символізуючи стабільність результатів на шляху досягнення акмеологічного часу-простору.

Ключові слова: музикознавче акме, музикознавча життєтворчість, вікове музикознавство другого типу, музикознавча акмеологія, акмеограма.

Рощенко Елена Георгиевна, доктор искусствоведения, профрессор, заведующая кафедры теории и истории музыки Харьковской государственной академии культуры

Музыковедческое акме Наталии Савицкой: на пути к музыкологической акмеологии

Цель работы - раскрыть сущность музиковедческого акме Наталии Савицкой на основе разработки основ музыкологической акмеологии. Методология исследования базируется на привлечении интердисциплинарного подхода, основ фундаментального музыковедения, акмеоцентрического подхода, введенного для опоры на совокупность методов акмеологических наук с целью системного изучения пути музыканта-ученого к профессионально-творческому совершенству. Научная новизна обусловлена раскрытием сущности музыковедческого акме Н. Савицкой, введением понятия музыковедческое жизнетворчество, обоснованием необходимости разработки музыкологической акмеологии. Получила развитие структура возрастного музыковедения - научного invention H. Савицкой: его второй тип предполагает анализ жизнетворчества музыковеда сквозь призму эволюции научного мышления; третий тип направлен на изучение личности исполнителя, исполнительского жизнетворчества - воплощения возрастных изменений в развитии творческой личности. Методология возрастного музыковедения срабатывает после окончания жизнетворчества индивидуума: тогда жизнетворческая дуга, прочерченная душой и трудом ученого-художника, выстраивается в полном объеме; происходит дистанцирование от созерцающего её акмеограму исследовательского взгляда. Последнее исследование Н. Савицкой - выражение музыковедческого акме: воплощение расцветшего таланта, совершенства научной мысли, духовной и профессиональной зрелости, кульминация музыковедческого жизнетворчества, способности дать объективную оценку собственным научным концепциям и рефлексиям, концепционностью и лаконизмом. Изучение вершинных достижений научнотворческой личности в процессе индивидуального развития профессиональной судьбы музыканта/музыковеда требует разработки основ музыкологической акмеологии - междисциплинарной науки о профессионально-личностном самосовершенствовании художника. В состав фундаментальной акмеологии, базирующейся на системе акмеологических наук, должна войти музыкологическая акмеология, основанная на взаимодействии истории, биографиики, психологии, педагогики, культурологии, социологии, классических направлений науки про музыку, с целью комплексного изучения личности музыканта-ученого, достигшего звездного часа в творчестве. Выводы. В личности Н. Савицкой-музыковеда, чьи труды отличает своеобразие исследовательского «почерка», свободное объединение фрилософско-художественного типа мышления, научного обобщения и литературности изложения, проступала красота мудрой женщины. Траектория жизнетворчества Н. Савицкой свидетельствует о свойственном героине музыкологической акмеологии достижении профессиональных высот, совершенства научного произведения. Кульминация жизненной дуги Н. Савицкой совпала с финалом жизни музыковеда. Личность Н. Савицкой соответствует критериям профессиональноличностного совершенства научно-творческого субъекта, который пребывает на вершине музыковедческой науки, символизируя стабильность результатов на пути достижения акмеологического времени-пространства.

Ключевые слова: музыковедческое акме, музыковедческое жизнетворчество, возрастное музыковедение второго типа, музыковедческая акмеология, акмеограма.

Roshchenko Olena, Doctor of Art Criticism, Professor, HoD of History and Theory of Music, Kharkiv State Academy of Culture

Musicological acme of Nataliia Savytska: on the way toward Musicological Acmeology

Purpose of the Article is to reveal the essence of musicological acme of Nataliia Savytska on the basis of laying the groundwork for musicological acmeology. The research methodology is based on the interdisciplinary approach, the fundamental 
principles of musicology, and the acmeocentric approach applied for the sake of relying on a set of methods of acmeological sciences in order to systematically study the path of the musician-artist to professional and creative excellence. The novelty consists in revealing the essence of the musicological acme of N. Savytska, the introduction of the concept of musicological creative life, the substantiation of the need for the development of musicological acmeology. The study investigates this issue by examining the structure of age-specific musicology - the scientific invention of N. Savytska: its second type involves an analysis of the musicologist's creative life from the perspective of the evolution of scientific thinking; the third kind is aimed at studying the performer's personality, performing creative life the embodiment of age-specific changes in the development of the creative person. The methodology of the age-specific musicology activates on completing the creative life of an individual: then the creative life arc, drawn by the soul and the work of the artist, is built up in full; there is a distancing from observing its acmeogram of the research eye. The last research by N. Savytska is an expression of musicological acme: the embodiment of flourishing talent, the perfection of scientific thought, spiritual and professional maturity, the culmination of musicological creative life, which is distinguished by the ability to provide an objective assessment of her own scientific concepts and reflections, conceptuality and laconicism. Studying the top achievements of a scientific and creative personality in the process of individual development of a career life of a musician/musicologist requires laying the groundwork for musicological acmeology - an interdisciplinary science of professional self-perfection of the artist. The structure of fundamental acmeology, formed by the system of acmeological sciences, should include musicological acmeology based on the interdisciplinary interaction of history, biographical studies, psychology, pedagogy, cultural studies, sociology, the classical directions of the art of music, with a view to comprehensively studying the personality of the musician-artist, who achieved the high point of his/her career. Conclusions. In the person of N. Savytska-musicologist, whose works are distinguished by the peculiarity of the research "writing style", the free combination of the philosophical and artistic type of thinking, scientific generalization and the literary layout, the beauty of a wise woman has been formed. The path of the creative life of N. Savytska demonstrates the penchant for rising to eminence in her profession, the excellence of the scientific work inherent in the heroic figure of musicological acmeology. The culmination of the life arc of N. Savytska coincided with the end of the musicologist's life. The personality of N. Savytska meets the criteria of professional and personal excellence of the scientific and creative subject, who is at the top of musicology, symbolizing the stability of the results on the way to achieving the acmeological time-space.

Key words: musicological acme, musicological creative life, age-specific musicology of the second type, musicological acmeology, acmeogram.

Актуальність роботи. Серед перспектив досліджень Новітньої доби - можливість поширення закладених у дослідницькому напряму ідей (за умов їх відповідної специфікації) на інші предмети та сфери науково-творчого пізнання. Цим особливостям Новітньої наукології відповідають праці Наталії Савицької [], фундатора вікового музикознавства, що символізує досягнення вченим музикознавчого акме, професійноособистісної вершини. На основі поєднання методів вікової психології та засад фрундаментального музикознавства Н. Савицька розробила теорію стильової еволюції композиторської творчості як відображення вікових змін у свідомості Майстра. Вивченню творчої особистості музиканта/музикознавця в її шляху до професійно-творчої досконалості сприятиме музикологічна акмеологія, розробка якої - нагальне завдання фундаментального музикознавства.

Аналіз останніх досліджень та публікацій. Теоретичну базу дослідження складає аналіз праць Н.Савицької [6; 7] з позиції їх тлумачення як втілення музикознавчого акме їх автора; акмеологічні дослідження О. Є. Антонової [1], В.М. Антонова [2], А. Баран [3], Н. В. Кузьміної [5]. 3 позицій розгляду формування передумов музикологічної акмеології залучені праці О. Козаренка [4], О. Самойленко [8], В. Федоришин [9].

Виклад основного матеріалу. Вікове музикознавство того фрормату, що його затвердила Н. Савицька, передбачає розгляд композиторської життєтворчості від їі першої до фрінальної сцени. Композиторська особистість, що відтворюється та метаморфізує, в дослідженні Н. Савицької постає як результат цілісності життєвого і креативного фракторів у синхронному розвитку індивідуального та професійного. Розвиток композиторської життєтворчості відбувається за законами драми, фрази якої - пролог - епілог, розвиток кульмінація - розв'язка - зазнають нескінченних індивідуалізованих варіантів, корегують численні «біографічні сценарії» [6, 214] та їх типологічні моделі [6, 215], немовби запрограмовані у величному і незбагненному Theatrum mundi, якщо під таким розуміти зафіксований в нотному тексті творчий спадок як відображення нероздільності життя і творчості Митця. Вивчення життєтворчості композиторів дозволяють тлумачити їх носіїв як геніїв біографіi, індивідуальні втілення загальнолюдського духовного «я». Завдяки винайденню загальних закономірностей, що об'єднують розвиток композиторських індивідуальностей на основі властивих їм вселюдських якостей, в працях Н. Савицької відбувається проникнення у глибини найпотаємнішого - в сутність того Божественного першонатхнення, завдячуючи якому відбувається створення шедевру.

Розробка вікового музикознавства - наукового invention Н. Савицької, підготовлена усім плином розвитку музикознавства. Поруч із інноваційною якістю, концепція Н. Савицької від початку володіла зв'язками з музикознавством «традиційним». За цих умов вчення вікового музикознавства, переходячи до рангу фундаментальної науки, швидко набуло значення сталого напряму науки про музику. Універсалізм і науковий потенціал вікового музикознавства, невичерпаність проблематики дослідження, далекого «від наукового герметизму» (за Н. Савицькою), можливість поширення його методологічних засад на вивчення тих композиторських особистостей, що не були залучені до дослідження, уможливило розвиток його положень численними послідовниками. Зокрема, Цао Хе підкреслив: «можливість застосування концепції композиторської життєтворчості ... до аналізу періодизації вокальної творчості китайського композитора Шан Деї засвідчує властивий праці української дослідниці універсальний характер» [10, 44].

Час вікового музикознавства як спеціальної наукової галузі настав на початку XXI століття, коли склалися об'єктивні умови його виникнення. Серед них - необхідне для фрормування наукової концепції відчуження від матеріалу дослідження: часова відстань між романтизмом і пост-постмодернізмом виявилася достатньо вагомою для створення нового наукового напряму в класичному музикознавстві. Розробляючи критерії періодизації композиторської життєтворчості, Н. Савицька підкреслює: «...схематизація живого, 
нерегламентованого процесу самореалізації здійснюється на двох рівнях: динамічному ... і статичному, що фріксує синхронний подієвий зріз жииттєсходження» $[6,159]$. Про діалектику мислення вченого свідчить підхід до вивчення специфіки художнього мислення митця на пізньому етапі композиторської життєтворчості. Дослідниця фріксує увагу на домінування авторефлексійного, автобіографічного узагальнень 3 власного минулого. Акцентування суб'єктивного, мікрокосмічного в оцінках Н. Савицької не затьмарює притаманну пізньому періоду творчості композитора властивість виходу до об'єктивно-символічного осмислення дійсності, закономірностей макро-космічного рівня. Вивчення феномену віку основано на поєднанні часових вимірів - хронологічного (односпрямованого й лінійного) та психологічного (оберненого та зворотнього), що надає дослідженню вікового музикознавства ознак метафізики історії.

Серед перспектив дослідження Н. Савицької, від початку націленого на вивчення композиторської творчості під кутом зору вікових зрушень, - його поширення на вивчення особистості музикознавця, чия життєтворчість також підвладна волі, владі та регламентації, встановлених великим Хроносом. Зміна предмета дослідження має відбуватися завдяки екстраполяції та специфікації положень вчення про вікові зрушення на музикознавчу життєтворчість: у дзеркальних глибинах вікового музикознавства знайде відображення творчий портрет музикознавця, окреслений ознаками вікової приналежності.

Передумовою поширення сукупності положень дослідження Н. Савицької на життєтворчість музикознавця постає багатовимірність змісту вікового музикознавства, яке має існувати в трьох типах, в залежності від предмета вивчення. Вчення Н. Савицької про композиторську особистість, яка розкривається в процесі динаміки вікових змін, постає як вікове музикознавство першого типу. Вікове музикознавство другого типу передбачає аналіз життєтворчості музикознавця (музикознавчої особистості) крізь призму завершених праць та начерків, що відображають еволюцію наукового стилю мислення автора. Одначе композиторським і музикознавчим вимірами зміст вікового музикознавства не вичерпується. Вікове музикознавство третього типу слід спрямувати на вивчення виконавської життєтворчості. Об'єктивна спільність між трьома типами наукового музикознавства взаємообумовлених предметів дослідження обумовлює властиву їм певну методологічну єдність. Становлення музикознавчої та виконавської особистостей зазнає подібні до композиторської індивідуальності еволюційні зрушення, відображені у музикознавчих або виконавських творах.

Підкреслимо, що пропозиції щодо розширення наукового поля вікового музикознавства були висловлені автором цієї роботи в опонентському відзиві на докторську дисертацію Н. Савицької, яка позитивно їх прийняла. Цей факт надає певної освяченості науковій розвідці щодо визначення перспектив розвитку концепції вікового музикознавства.

Методологія вікового музикознавства спрацьовує лише після закінчення життєтворчості індивідууму. Саме тоді життєтворча дуга, прочерчена душею й працею митця упродовж його земного буття, вибудовується у повному обсязі; лише тоді набуває необхідного дистанціювання/відсторонення від спостерігаючого за її контуром дослідницького ока, об'єктивується, підкорюючись фрункції предмету вивчення. Лише тоді набуває оформлення «біографічний сценарій» $[6,214]$ музиканта/музикознавця, що утворює предмет вивчення вікового музикознавства.

...Якщо шукати прикладів швидкоплинності безжального Хроносу, що скеровує розвиток музикознавчої життєтворчості науково та художньо обдарованої особистості, чи не стане найбільш красномовною ілюстрацією вірності результатів дослідження вивчення «біографрічного сценарію», який випав на долю авторки теорії вікового музикознавства - Наталії Савицької? Від риторичного за своєю суттю питання час перейти до вирішення наукового завдання екстраполяції-специфікації положень теорії, розробленої на основі вивчення життєтворчих принципів композиторської індивідуальності, на особистість музикознавця. Науковий спадок Н. Савицької, невід'ємний від їі особистості, відобразив музикознавчу життєтворчість дослідниці, утворивши предмет дослідження вікового музикознавства другого типу.

Останнє монументальне дослідження Наталії Савицької є виразом досягнутого нею музикознавчого акме - втіленням досконалості та краси наукової думки, духовної і професійної зрілості, символом вершини музикознавчої життєтворчості автора. Здібність надання об'єктивної оцінки власним науковим рефрлексіям; концепційність та лаконізм; виваженість спостережень та висновків; поєднання раціонально-аналітичного типу мислення із відчуттям випромінюваної музичним шедевром поетичної краси, натхненної психо-віковим станом творця - такими є ознаки музикознавчого акме Н. Савицької. Останнє монументальне дослідження, як полуденне сонце, освітлює пізній стиль наукової життєтворчості музикознавця, зберігає духовну атмосферу, що вона створювала її навколо себе, гармонію зовнішнього та внутрішнього, що вирізняла науково-творчу постать музикознавця, який досяг фрази акме.

Вивчення проявів вищого ступеню індивідуального розвитку, досягнення квітучої пори в професійній долі музиканта/музикознавця потребує розробки засад музикологічної акмеології. Формування музикологічної акмеології - науки про професійно-особистістне самовдосконалення - обумовлено системною сутністю міждисциплінарної «науки XXI століття» (у відповідності до теми Міжнародної науковопрактичної конференції Української академії акмеології). Акмеологічні дослідницькі напрями специфікуються в залежності від професійної спрямованості особистості. А. Баран виокремила види професійної акмеології: педагогічний, військовий, соціальний, шкільний, медичний, юридичний, а також акмеологію управління; креативну акмеологію, синергетичну акмеологію; акмеологію освіти; етнологічну акмеологію [3]. Фундаментальну акмеологію як науку про досягнення вершин професіоналізму [5] утворює система 
акмеологічних наук, до складу яких має увійти музикознавча акмеологія. В українській науці склалися умови формування музикознавчої акмеології: В. Федоришин розробив засади «фрахової підготовки майбутніх учителів музики на акмеологічних засадах» [9]; акмеологічні ракурси музиконавчого дослідження властиві працям О. Козаренка [4], Н. Савицької [6; 7] О. Самойленко [8]. Музикознавча акмеологія на основі взаємодії історії, біографріки, психології, педагогіки, культурології, соціології має ґрунтуватися на класичних напрямах науки про музику (теоретичного, історичного, виконавського). Загальна акмелогія постає як наукова дисципліна, «що вивчає закономірності й феномен розвитку людини до ступеня їі зрілості, при досягненні нею найбільш високого рівня в цьому розвитку» $[1,17]$. Музикознавча акмеологія має бути націленою на комплексне вивчення особистості музиканта/науковця, який досяг зоряної години, тлумаченні його творчості як виразу розквітлої індивідуальності; спиратися не лише на акмеологічний, але й акмеоцентричний підхід, що передбачає спирання на сукупність методів акмеологічних наук з метою системного вивчення шляху до професійно-творчої досконалості музиканта-науковця.

Якою ж постає постать музикознавця, що криється за науковим дослідженням щодо композиторської життєтворчості? Що представляє собою пережита його автором музикознавча драма - «траєкторія розвитку особистості» $[6,5]$ сконструйована упродовж блискучої та лаконічної музикознавчої кар'єри?

В особі Наталії Савицької як «акме-людини» (за В. М. Антоновим [2]), музикознавця, праці якого вирізняє індивідуальний стиль музикознавчого мислення, своєрідність дослідницького «почерку», вільне поєднання філософсько-художнього типу мислення, наукового узагальнення і літературності викладення, проступала краса мудрої жінки. Траєкторія життєтворчості Наталії Савицької на всіх етапах її особистісного і наукового самоздійснення засвідчує властиве героїні авторського музикознавства безперервне тяжіння до досягнення професійних висот, абсолютної досконалості наукового твору - від концепції до мови, від структури до змісту, від цілого до останнього слова. Життєтворча траєкторія, вибудувана Н. Савицькою, мала свою кульмінацію. Вона співпала з фіналом життя музикознавця монументальної праці, з якою пов'язане остаточне визнання розквітлого таланту вченого. Після фрінальної кульмінації у життєтворчості Наталії Савицької була ще й кода: у ії межах швидкоплинна радість, обумовлена надіями на реалізацію сміливих злетів наукової думки, змінилися гіркотою мученицького прощання, усвідомленням недосяжної нездійсненності ідей.

Лише після завершення науково-творчого шляху Наталії Савицької, жорстоко перерваного по волі всевладного Хроносу, стало очевидним, що дослідження, присвячене затвердженню позицій вікового музикознавства у сфрері композиторської життєтворчості, набуло значення останньої монументальної праці, головного завдання і результату науково-творчої життєтворчості дослідниці. Безліч задумів, що одночасно із життєтворчою концепцію вирювали в її душі й свідомості, на жаль, залишилися незавершеними.

Образ Наталії Савицької, концепція якої засвідчує досягнення музикознавцем вищої фази самовиразу в шляху до вершини, відповідає критеріям професійно-особистісної досконалості науково-творчого суб'єкта предмету вивчення у музикознавчій акмеології. Перебування на вершині музикознавчої науки - символ стабільності результатів на шляху досягнення акмеологічного часу-простору в професійно-особистісній сфері.

«Біографрічний сценарій», що випав на долю Наталії Савицької (його композиторські аналоги розглянуто дослідницею), типовий і, поруч з тим, індивідуально специфікований. Дарована їй і нею створена життєтворчість постає як фрагмент дуги людського життя, що її проходить від природи досконала людина. Згідно відтвореної автором «Божественної комедії» вікової дуги, повний часовий обсяг людського життя дорівнює 70 рокам. Вершиною цієї дуги, вищою крапкою в її оформленні постає 35 - 37-річчя в житті людини: саме в цей час їй відкривається краса Всесвіту, смисл власного минулого та майбутнього. Саме в цьому віці геніальній людині (за умов її надзвичайної працездатності та працелюбності) відкривається ії призначення створити шедеври в тому виді діяльності, який вона обрала. Та життєтворча дуга, що ії було призначено сконструювати Наталії Савицькій, має характерну змістовну конфігурацію. Ії опис міститься у праці авторки концепції вікового музикознавства: «пік продуктивності ... співпадає з інтервалом вікового розквіту від 30 до 40 років, однак, найдосконаліші творіння майже завжди народжувалися у полудень віку - 50-60 років» [6, 10]. Такий тип життєтворчої дуги, «непростий шлях сходження до пізніх вершин» [6, 6], описаний у дослідженні композиторської особистості з психовікових позицій, відбився в долі його авторки. Дуга музикознавчої життєтворчості Наталії Савицької завершується кульмінацією, що співпадає із шляхетним віком, післяполуденним часом у порах людського віку. Кульмінацією постає створене нею дослідження композиторського стилю, етапи розвитку якого визначаються віковими зрушеннями. В авторському музикознавстві Н. Савицької відчутний прояв третьої моделі типології біографічних сценаріїв, який розвивається за «крещендуючим принципом» $[6,217]$. Його сутність полягає у «природному розвитку таланту, що сягає вершини в фразі акме - ... вищого вікового розквіту індивіда ...» [6, 217]. За концепцією авторки вікового музикознавства, акмеічний тип крещендуючого біографрічного сценарію представляють герої, Хронос життєтворчості яких вирізняють різні за віковими покажчиками життєтворчі дуги - Шуберт і СенСанс, Мендельсон і Брукнер, Шопен і Лисенко... За крещендуючим принципом розвивався і біографічний сценарій дослідниці, яка присвятила фінальний науковий твір вивченню закономірностей композиторської життєтворчості. Фінал творчого життя Н. Савицької, що його вирізняє взаємодія двох «життєвих подій»фази «найвищого розквіту» і «підведення підкумків» [6, 160], можна уподібнити віднайденій дослідницею логіці життєтворчої дуги Дж. Россіні, яку визначає «одночасовість цвітіння і закату» $[6,196]$.

У структурі життєтворчої дуги як своєрідної акмеограми, що відбиває етапи професійного становлення Н. Савицької, очевидний прояв демографічної (першої) типологічної моделі біографічного сценарію, згідно 3 
якою «акт народження генія є кінцевим результатом латентного накопичення здібностей багатьох генерацій однієї династії» [6, 215]. Об'єктивним відображенням вірності цього положення вікового музикознавства щодо його відбиття у структурі дуги земного буття дослідниці, є той факт, що саме батькові - Владиславу Олександровичу Швецю (відомому українському музикантові), «чий світлий образ назавжди залишиться непідвласним Хроносу» (з авторської присвяти монографії «Хронос композиторської життєтворчості» [6, 3]), Наталія Савицька присвятила свою доленосну роботу. Музичну генерацію родоводу Швець-Савицьких нині продовжує донька і онуки дослідниці.

Висновки. Положення щодо «зворотності психологічного віку» митця, розроблене Н. Савицькою, знаходить своєрідне віддзеркалення у музикознавчій індивідуальності автора концепції вікового музикознавства. Науково-творчу постать Н. Савицької слід віднести до того типу митця, який в юності виявляє духовну зрілість (подібно до Ф. Мендельсона, чия життєтворчість постала предметом аналізу в праці дослідниці), натомість у зрілому віці зберігає дитячий погляд на життя (на кшталт того, як у фріналі 4 Симфонії Г. Малера дитяча наївність набула значення найвищого прояву мудрості). В душі Н. Савицької поєднувалися прояви вікових полярностей - юнацький та зрілий типи вікової самосвідомості, що обумовило наявність ознак вікової подвійності, поєднання в єдиному життєвому часопросторі різних вікових градацій. Хронологічно музикознавче акме Н. Савицької відповідає «благородному віку» в долі творчої людини. Поруч з тим, музикознавчій особистості Н. Савицької властивий «розрив» між хронологічним і психологічним, внутрішньозовнішнім проявами «благородного віку». Якщо врахувати, що зовнішність відображує внутрішній світ творчої людини, істинну природу та духовний стан, якщо приділити увагу портретним властивостям авторки вчення про «вікове музикознавство», уможливляться наступні спостереження. Краса, ніжний погляд, легкий гумор, елегантність у всьому - від зовнішніх проявів жіночності до оформлення думок і почуттів - поставали як випромінювання світлої душі, тяжіючої до волі та досконалості. Наталія Савицька піднялася лише на початкову сходинку пізнього етапу, подумки прозріваючи ії наступні рівні, зберігши ознаки юнацького періоду життєтворчості, залишивши по собі пам'ять в образі посміхненого, мрійливого, граціозного білявого Янгола, в оболонці якого жив Геній.

Вивченню шляхів особистості музиканта/музикознавця до професійно-особистісної вершини сприятиме музикологічна акмеологія, розвиток якої постає як нагальне задання фрундаментального музикознавства та загальної акмеології.

\section{תimepamypa}

1.Антонов В. М. Синергетична акмеологія. URL: http://www.sworld.com.ua/konfer34/146.pdf.

2. Антонова О. Є. Акмеологічний підхід до визначення сутності педагогічної обдарованості // Акмеологія - наука XXI століття : матеріали III Міжнар. наук.-практ. конф. / Київ. ун-т ім. Бориса Грінченка. Київ, 2011. С. 17-22.

3. Баран А. Поняття та види акмеології: теоретичний аналіз // Вісн. Нац. ун-ту «Львів. політехніка». Серія: Юридичні науки. 2015. № 825. C. $109-115$.

4. Козаренко О. Тарас Шевченко і Микола Лисенко: акмеологічний рівень спілкування особистостей // Вісн. Львів. ун-ту. Серія: Мистецтвознавство. 2014. Вип 15. С. 20-23.

5. Кузьмина Н. В. Фундаментальная акмеология как важнейший ресурс процесса повышения продуктивности образования // Проблеми освіти : зб. наук. пр. Житомир-Київ, 2015. Вип. 84. С. 14-19.

6. Савицька Н. В. Вікові аспекти композиторської життєтворості : дис. ... д-ра мистецтвознавства : [спец.] 17.00 .03 «узичне мистецтво» / Нац. муз. акад. ім. П. І. Чайковського. Київ, 2009. 414 с.

7. Савицька Н. В. Хронос композиторської життєтворчості : монографія / Львів. нац. муз. акад. ім. М. В. Лисенка. Львів : Сполом, 2008. 320 c.

8. Самойленко О. І. Авторський стиль як конститутативна риса музикознавчого дослідження: акмеологічні обрії наукової теорії Наталії Савицької // Часоп. Нац. муз. акад. України ім. П. І. Чайковського. 2015. № 4 (29). С. 28-38.

9. Федоришин В. І. Теорія та методика фрахової підготовки майбутніх учителів музики на акмеологічних засадах : автореф. дис. ... д-ра пед. наук: [спец.] 13.00.02 «Теорія та методика музичного навчання» / Київ. Нац. пед. ун-т ім. М. П. Драгоманова. Київ, 2014. 46 с.

10. Цао Хе. Вокальна спадщина Шан Деї: синтез національних та європейських традицій : дис. ... канд. мистецтвознавства : спец. 17.00.03 «Музичне мистецтво». Сум. держ. пед. ун-т ім. А. С. Макаренка, Суми, 2019. 211 с.

\section{References}

1. Antonov V. M. Synergetic acmeology. Retrieved from http://www.sworld.com.ua/konfer34/146.pdf. [In Ukrainian].

2. Antonova, O. Je. (2011). Akmeologichesky approach to the definition of the essence of pedagogical giftedness. Materials III International scientific-practical conference. Akmeologiya - XXI century science (pp. 17-22). Kiev University Borys Grinchenko. Kyiv. [In Ukrainian].

3. Baran, A. (2015). Concepts and types of acmeology: theoretical analysis. Bulletin of Lviv Polytechnic National University. Series: Legal Sciences, 825, 109-115. Lviv. [In Ukrainian].

4. Cao Khe (2019). The vocal heritage of Shang Dai: a synthesis of national and European traditions. Extended abstract of candidate's thesis. Sumy State Pedagogical University named after AS Makarenko. Sumy. [In Ukrainian].

5. Fedoryshyn V. I. (2014). Theory and methods of professional training of future music teachers on the basis of acmeology. Doctor's thesis. National Pedagogical Dragomanov University. Kyiv. [In Ukrainian].

6. Kozarenko, O. (2014). Taras Shevchenko and Mykola Lysenko: acmeological level of personal communication. Visnyk of the Lviv University. Series Art Studies, 15, 20-23. Lviv. [In Ukrainian].

7. Kuzmina N. V. (2015). Fundamental acmeology as the most important resource of the process of increasing the productivity of education. Problems of education, 84, 14-19. Zhytomyr-Kiev. [In Russian].

8. Samojlenko O. I. (2015). Author's style as a constitutive feature of musicological research: acmeological horizons of the scientific theory of Natalia Savitskaya. A journal of the P. Tchaikovsky National Music Academy of Ukraine, 4, 22-38. [In Ukrainaian].

9. Savycjka N. V. (2008). Chronos composer's life-creations. Lviv : Spolom [In Ukrainian]. Ukrainian].

10. Savycjka N. V. (2009). Age aspects of composer's liveliness. Doctor's thesis. Tchaikovsky National Music Academy of Ukraine. Kyiv. [In 